\title{
Drug-Gene Interaction Between the Insertion/Deletion Polymorphism of the Angiotensin-Converting Enzyme Gene and Antihypertensive Therapy
}

\author{
Hedi Schelleman, Olaf H Klungel, Cornelia M van Duijn, Jacqueline CM Witteman, Albert Hofman, \\ Anthonius de Boer, and Bruno HCh Stricker
}

\begin{abstract}
BACKGROUND: Despite the availability of a variety of effective drugs, inadequate control of blood pressure is common. There are some indications that the angiotensin-converting enzyme (ACE) gene modifies the response to antihypertensive drugs, but the results have been inconclusive.
\end{abstract}

OBJECTIVE: To investigate whether the insertion/deletion polymorphism of the ACE gene modifies blood pressure differences among subjects using diuretics, $\beta$-blockers, calcium-channel antagonists, or ACE inhibitors.

METHODS: Data were used from the Rotterdam Study, a population-based, prospective, cohort study in the Netherlands, which started in 1990 and included 7983 subjects aged 55 years or older. Data from 3 subsequent cross-sectional investigations were used, as well. Subjects were included if they had high blood pressure during one or more examinations and/or used monotherapy with a diuretic, $\beta$-blocker, calcium-channel antagonist, or ACE inhibitor. A marginal, generalized, linear model was used to assess the association between the mean difference in systolic/diastolic blood pressure and antihypertensive classes stratified by the 3 genotypes.

RESULTS: In total, 3025 hypertensive individuals were included, and 6500 measurements of blood pressure were taken. The percentages of DD, ID, and II genotypes were $28.3 \%, 51.4 \%$, and $20.3 \%$, respectively. The mean differences in systolic blood pressure between the II and DD genotypes were $0.23 \mathrm{~mm} \mathrm{Hg}(95 \% \mathrm{Cl}-5.48$ to 5.94$)$ for diuretics, $-2.41 \mathrm{~mm} \mathrm{Hg}(95 \% \mathrm{Cl}-6.72$ to 1.90) for $\beta$-blockers, $2.12 \mathrm{~mm} \mathrm{Hg}(95 \% \mathrm{Cl}-4.64$ to 8.89$)$ for calcium-channel antagonists, and $-2.01 \mathrm{~mm} \mathrm{Hg}(95 \% \mathrm{Cl}-9.82$ to 5.79$)$ for ACE inhibitors.

CoNCLusions: The adjusted mean difference in diastolic and systolic blood pressure among diuretic, $\beta$-blocker, calcium-channel antagonist, or ACE inhibitor users was not modified by the ACE insertion/deletion polymorphism.

KEY WORDS: angiotensin-converting enzyme gene, polymorphism.

Ann Pharmacother 2006;40:212-8.

Published Online, 31 Jan 2006, www.theannals.com, DOI 10.1345/aph.1G316

T he renin-angiotensin system (RAS) regulates blood pressure and fluid homeostasis. Angiotensin-converting enzyme (ACE), which is one of the enzymes of the RAS, converts angiotensin I to the vasoactive angiotensin II and inactivates bradykinin. An insertion/deletion (I/D) polymorphism of the 187-bp Alu element in intron 16 of the ACE gene predicts approximately half of the interindividual variability in serum ACE levels. ${ }^{1}$ In general, individuals with the DD genotype have serum ACE levels that are twice

Author information provided at the end of the text. as high as those in individuals with the II genotype, ${ }^{1}$ although there is no clear correlation to blood pressure. ${ }^{2}$

Predicting the effect of an antihypertensive agent in a patient is difficult. To overcome this problem, researchers are investigating which genes influence the response to various antihypertensive drugs.

Some studies have investigated the effect of the ACE I/D polymorphism on blood pressure response in patients treated with ACE inhibitors ${ }^{3-11}$ and, less so, in patients treated with $\beta$-blockers., ${ }^{4,12} \beta$-Blockers reduce angiotensin II levels by inhibiting the $\beta$-adrenergic-mediated renin release from the kidneys. ${ }^{13}$ With regard to ACE in- 
hibitors, 3 studies indicated that subjects with the D allele had a stronger drug effect, ${ }^{8-10} 2$ indicated the I allele had a stronger effect, ${ }^{6,7}$ and 4 found no drug-gene effect. ${ }^{3-5,11}$ No drug-gene interaction was found in studies of subjects using $\beta$-blockers., ${ }^{412}$ Due to conflicting results, it remains unclear whether the I/D polymorphism of the ACE gene influences the response to ACE inhibitors or $\beta$-blockers.

Diuretics and calcium-channel antagonists are also influenced by the RAS (ie, by the counter regulatory system). For example, diuretic therapy leads to salt loss, which in turn results in volume depletion, causing an increase in plasma renin activity. ${ }^{14}$ Calcium-channel antagonists block the inward movement of calcium by binding to L-type calcium channels in the heart and in smooth muscle of the coronary and peripheral vasculature. This could result in activation of the RAS. ${ }^{15}$

The purpose of this study was to evaluate the relationship between the I/D polymorphism of the ACE gene on the mean difference in systolic blood pressure (SBP) and diastolic blood pressure (DBP) among subjects who used diuretics, $\beta$-blockers, calcium-channel antagonists, and/or ACE inhibitors.

\section{Methods}

\section{SETTING}

The Rotterdam Study started in 1990 as a population-based, prospective, follow-up study. All 10275 residents of the Rotterdam suburb of Ommoord who were 55 years or older were invited to participate. The aim of the Rotterdam Study was to investigate determinants of disease occurrence and progression in the elderly. Our study was approved by the Medical Ethics Committee of Erasmus University and conducted in compliance with their requirements. In total, 7983 (78\%) residents gave written informed consent and, of 6869 (86\%), the ACE genotype was assessed. Baseline measurements were taken until 1993. The design of this population-based study has been described elsewhere. ${ }^{16}$

The baseline examination included an interview on demographics, current health status, medical history, family history of diseases, smoking habits, and current use of medication. During a physical examination, blood pressure, weight, and height were measured and blood was drawn for DNA extraction. Blood pressure was measured, with subjects in a sitting position, at the right upper arm with a random-zero sphygmomanometer. The average of the 2 measurements, separated by a count of pulse rate, was used in the analysis. All participants were subsequently examined every 2-3 years (1993-1995, 1997-1999). Blood pressure data from all 3 examinations were used in this study.

Pharmacy records were available for approximately $99 \%$ of the cohort as of January 1, 1991. These records include the name of the drug, the day of dispensing, the dosage form, the number of units dispensed, the prescribed daily dose (PDD), and the Anatomical Therapeutic Chemical code of the drug. ${ }^{17,18}$

\section{COHORT AND OUTCOME DEFINITION}

The study population included all individuals in the Rotterdam Study who had hypertension, for whom the ACE genotype was assessed, and for whom one or more blood pressure measurements were available. We defined hypertension as one or more blood pressure measurement(s) dur- ing follow-up that met one of the following criteria: SBP $160 \mathrm{~mm} \mathrm{Hg}$ or higher and/or DBP $95 \mathrm{~mm} \mathrm{Hg}$ or higher. Subjects who used antihypertensive drugs during follow-up were also defined as hypertensive. When a blood pressure measurement was taken, we assessed whether a prescription was filled by the pharmacy on the same day. The duration of each prescription was calculated by dividing the number of dispensed tablets or capsules by the prescribed daily number. When the measurement date fell within the usage period, the subject was considered as currently exposed. When more than one antihypertensive drug class was used at the time of the blood pressure measurement, the measurement was excluded.

Antihypertensive drug treatment was classified into 4 groups: diuretics, $\beta$-blockers, calcium-channel antagonists, and ACE inhibitors. Subjects could switch between no treatment and different antihypertensive drug classes and between different antihypertensive drug classes. Due to small numbers for other antihypertensive drug classes, only subjects using drugs from the 4 groups listed above were included in the analysis. Pharmacy records were available as of January 1, 1991. Nevertheless, blood pressure measurements from 1990 were included if an individual did not use an antihypertensive drug, according to a self-reported questionnaire, and did not start antihypertensive therapy before July 1, 1991, according to the pharmacy dispensing records. The end of the study period was set at December 31, 1999.

\section{POTENTIAL CONFOUNDERS AND EFFECT MODIFIERS}

The potential confounders considered were age; gender; body mass index (BMI); defined daily dose (DDD); examination time (1st, 2nd, or 3rd); smoking at baseline; history of myocardial infarction; diabetes mellitus at baseline; current use of nitrates, statins, or nonsteroidal antiinflammatory drugs; use of another antihypertensive drug class 2 weeks prior to the blood pressure measurement; use of an antihypertensive drug for 6 of the 8 weeks prior to the blood pressure measurement; and the cumulative number of days an antihypertensive was used. History of myocardial infarction was self-reported and confirmed by a physician or demonstrated on a baseline electrocardiogram. To compare dosages of different antihypertensive drugs, we used the PDD expressed as the number of DDDs per day. The DDD is defined as the average daily dose for the main indication in an adult weighing $70 \mathrm{~kg} .{ }^{18}$ DDDs provide a fixed unit of measurement independent of price and formulation, enabling the researcher to assess trends in drug consumption and perform comparisons among population groups.

Smoking was considered an effect modifier since smoking and the D allele have been associated with increased generation of angiotensin II. ${ }^{19}$

\section{GENOTYPE}

The I and D allele of the ACE gene were identified on the basis of polymerase chain reaction (PCR) technique in accordance with the method described by Lindpaintner et al., ${ }^{17}$ with some modifications. Because the $\mathrm{D}$ allele in heterozygous samples is preferentially amplified, there is a tendency toward misclassification of $4-5 \%$ of the ID to DD genotypes. For this reason, a second PCR was performed with a primer pair that recognizes an insertion-specific sequence (5'TGG GAC CAC AGC GCC CAC TAC3' and 5'TCG CCA GCC CTC CCA TGC CCA TAA3'). The reaction yielded a 335 bp amplicon only if the I allele was present. Two independent investigators read pictures from each gel, and all ambiguous samples were analyzed a second time.

\section{STATISTICAL ANALYSIS}

We used ANOVA (continuous variables) and $\chi^{2}$ testing (categorical variables) to compare baseline characteristics of people with different 
genotypes. To compare the difference in DDDs for each examination, an ANOVA was used, stratified by genotype. A marginal, generalized, linear model was used to investigate any association between I/D polymorphism of the ACE gene and antihypertensive treatment for 2 outcomes: mean difference in SBP and DBP. A p value of 0.05 or less was considered statistically significant. Since subjects could have 1, 2, or 3 measurements, the generalized linear model was used to account for intraperson correlations among repeated measurements. The covariance matrix of the repeated dependent measurements was unstructured, and data were analyzed using SAS statistical software and corrected for potential confounders.

We performed 2 analyses. In the first, we compared the mean SBP and DBP levels among the different genotype groups (DD, ID, II) for untreated and treated patients. The reference group consisted of untreated subjects with the DD genotype.

In the second analysis, we focused on the drug-gene interaction by comparing the mean SBP and DBP levels among the different genotype groups for subjects using the same antihypertensive drug class. The reference group consisted of subjects with the DD genotype who had a prescription for the antihypertensive drug class in question. The mean SBP and DBP of treated subjects were defined as the mean SBP or DBP of subjects who used the antihypertensive drug class in question minus the mean SBP or DBP in untreated subjects with the same genotype.

\section{Results}

Of the 6869 subjects who participated in the Rotterdam Study between January 1, 1990, and December 31, 1999, 3025 were classified as hypertensive and had a total of 6500 blood pressure measurements. In total, 28.3\%, $51.4 \%$, and $20.3 \%$ had the DD, ID, and II genotypes, respectively. Of this population, 431 used diuretics (603 measurements), 745 used $\beta$-blockers (1078 measurements), 306 used calcium-channel antagonists (400 mea- surements), and 317 used ACE inhibitors (420 measurements). A person could switch from one antihypertensive drug class to another. Baseline characteristics at the first examination are presented in Table 1 . The mean \pm SD DDD values at baseline for diuretics were $0.81 \pm 0.44$, for $\beta$-blockers $0.67 \pm 0.17$, for calcium-channel antagonists $0.79 \pm 0.43$, and for ACE inhibitors $1.01 \pm 0.63$. During the first examination round, 855 subjects were treated with an antihypertensive. During the 3 examination rounds, there was no statistically significant difference in the DDDs among the genotype groups for any of the antihypertensive drug classes listed above.

In the univariate analysis, without correction for potential confounders, none of the antihypertensive drug classes was associated with a significant decrease in the mean difference in SBP or DBP for the 3 genotype groups (data not shown). After adjustment for potential confounders, the ACE gene did not significantly influence the mean difference in SBP (ID vs DD $=0.42 \mathrm{~mm} \mathrm{Hg}, 95 \% \mathrm{CI}-5.18$ to 6.01; II vs DD $=-1.67 \mathrm{~mm} \mathrm{Hg}, 95 \% \mathrm{CI}-9.60$ to 6.27 ) or DBP (ID vs DD $=-0.21 \mathrm{~mm} \mathrm{Hg}, 95 \% \mathrm{CI}-3.24$ to 2.82; II vs $\mathrm{DD}=-0.84 \mathrm{~mm} \mathrm{Hg}, 95 \% \mathrm{CI}-5.19$ to 3.51 ) when all antihypertensive drugs were combined. The adjusted mean difference in SBP and DBP is shown in Figures 1 and 2, with the mean SBP or DBP levels in untreated subjects with the DD genotype as a reference. Subjects with the DD genotype who used diuretics had a $5.19 \mathrm{~mm} \mathrm{Hg}(95 \% \mathrm{CI}$ -10.16 to 0.78$)$ lower mean SBP and $0.44 \mathrm{~mm} \mathrm{Hg}(95 \%$ $\mathrm{CI}-3.76$ to 2.88 ) lower mean DBP compared with untreated subjects with the same genotype.

\begin{tabular}{|c|c|c|c|c|c|c|}
\hline \multirow[b]{2}{*}{ Variable } & \multicolumn{3}{|c|}{ Untreated } & \multicolumn{3}{|c|}{ Treated } \\
\hline & $\begin{array}{c}\text { DD } \\
(n=452)\end{array}$ & $\begin{array}{c}\text { ID } \\
(n=896)\end{array}$ & $\begin{array}{c}\text { II } \\
(\mathrm{n}=357)\end{array}$ & $\begin{array}{c}\text { DD } \\
(n=265)\end{array}$ & $\begin{array}{l}\text { ID } \\
(n=415)\end{array}$ & $\begin{array}{c}\text { II } \\
(n=175)\end{array}$ \\
\hline Gender (M), n (\%) & $172(38.1)$ & $370(41.3)$ & $139(38.9)$ & $93(35.1)$ & $168(40.5)$ & $61(34.9)$ \\
\hline Age $(y)$ & $70.1 \pm 8.9$ & $69.8 \pm 8.4$ & $69.2 \pm 8.5$ & $71.4 \pm 9.1$ & $71.3 \pm 8.9$ & $70.3 \pm 9.35$ \\
\hline $\mathrm{SBP}(\mathrm{mm} \mathrm{Hg})$ & $154.6 \pm 21.8$ & $153.4 \pm 21.3$ & $152.2 \pm 22.8$ & $145.1 \pm 22.1$ & $145.3 \pm 23.3$ & $142.5 \pm 23.3$ \\
\hline $\mathrm{DBP}(\mathrm{mm} \mathrm{Hg})$ & $79.0 \pm 11.9$ & $78.7 \pm 12.2$ & $79.8 \pm 12.4$ & $75.2 \pm 10.9$ & $76.1 \pm 11.9$ & $74.7 \pm 13.2$ \\
\hline BMI $\left(\mathrm{kg} / \mathrm{m}^{2}\right)$ & $26.5 \pm 3.5$ & $26.3 \pm 3.5$ & $26.3 \pm 3.4$ & $27.0 \pm 3.9$ & $27.2 \pm 3.7$ & $27.3 \pm 4.1$ \\
\hline Diabetes, n (\%) & $51(11.6)$ & $104(12.0)$ & $42(12.1)$ & $27(10.3)$ & $72(17.4)$ & $24(14.0)^{\mathbf{b}}$ \\
\hline \multicolumn{7}{|l|}{ Smoking, $\mathrm{n}(\%)$} \\
\hline current & $74(16.7)$ & $195(22.1)$ & $73(20.7)$ & $39(15.0)$ & $70(17.0)$ & $31(17.9)$ \\
\hline past & $196(44.2)$ & $358(40.5)$ & $157(44.6)$ & $113(43.5)$ & $184(44.7)$ & 77 (44.5) \\
\hline never & $173(39.1)$ & $330(37.4)$ & $122(34.7)$ & $108(41.5)$ & $158(38.3)$ & $65(37.6)$ \\
\hline \multicolumn{7}{|l|}{ Drug therapy, n (\%) } \\
\hline diuretics & & & & $77(33.6)$ & $104(45.4)$ & $48(21.0)$ \\
\hline$\beta$-blockers & & & & $116(30.3)$ & $179(46.9)$ & $87(22.8)$ \\
\hline calcium-channel antagonists & & & & $34(27.4)$ & $69(55.6)$ & $21(16.9)$ \\
\hline ACE inhibitors & & & & $38(31.7)$ & $63(52.5)$ & $19(15.8)$ \\
\hline $\begin{array}{l}\text { ACE }=\text { angiotensin-converting } \\
\text { aValues represent mean } \pm \text { SD } f \\
\text { bS Significantly different in treate }\end{array}$ & $\begin{array}{l}\text { yme; BMI = } \\
\text { continuous v } \\
\text { untreated g }\end{array}$ & $\begin{array}{l}\text { mass index; } D \\
\text { es or numbers } \\
\text { ( } p \text { value }<0.0\end{array}$ & $\begin{array}{l}\text { diastolic bloo } \\
\text { for dichotomo }\end{array}$ & $\begin{array}{l}\text { ure; SBP = s } \\
\text { bles. }\end{array}$ & ic blood pressur & \\
\hline
\end{tabular}


In addition, we investigated whether there was an interaction between the ACE I/D polymorphism and diuretics, $\beta$-blockers, calcium-channel antagonists, and/or ACE inhibitors (Figure 3). The reference in this analysis was the mean SBP or DBP of subjects with the DD genotype using the investigated antihypertensive drug. Diuretic users with the II genotype had a $0.23 \mathrm{~mm} \mathrm{Hg}(95 \% \mathrm{CI}-5.48$ to 5.94$)$ higher mean SBP and $0.81 \mathrm{~mm} \mathrm{Hg}(95 \% \mathrm{CI}-4.14$ to 2.52) lower mean DBP compared with diuretic users with the DD genotype.

After adjustment for the covariates, there was only a trend toward an association with the II genotype versus the DD genotype in patients treated with a $\beta$-blocker $(\mathrm{p}=$ 0.096). However, there was no dose-response relationship with regard to blood pressure with the I allele.

In addition, because previous research in the Rotterdam Study found a smoking-dependent effect of the ACE gene on blood pressure in smokers, ${ }^{20}$ our study assessed the

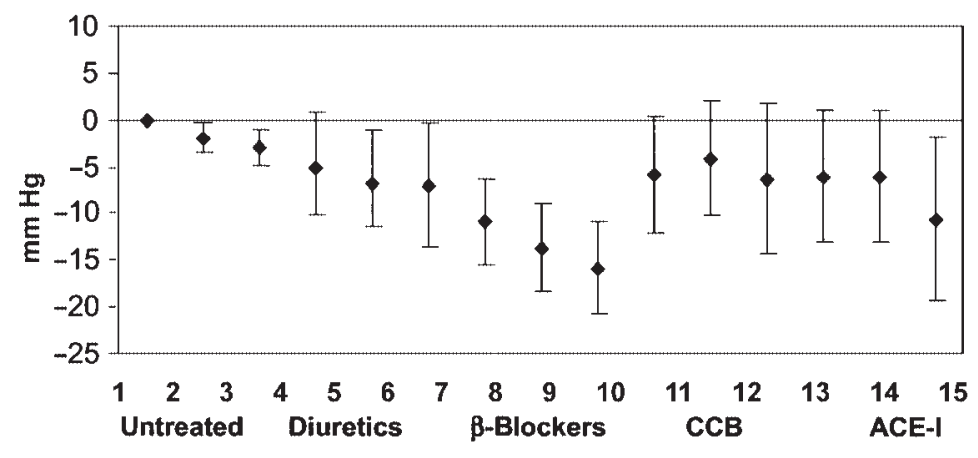

Figure 1. Adjusted mean systolic blood pressure among subjects using antihypertensive drugs and subjects who were not treated for the 3 ACE genotypes; untreated subjects with the DD genotype were used as reference. ACE-I = angiotensin-converting enzyme inhibitors: $\mathrm{CCB}=$ calcium-channel antagonists. $1=\mathrm{DD}$ untreated; $2=\mathrm{ID}$ untreated; $3=\mathrm{II}$ untreated; 4 $=\mathrm{DD}$ diuretics; $5=\mathrm{ID}$ diuretics; $6=\mathrm{II}$ diuretics; $7=\mathrm{DD} \beta$-blockers; $8=\mathrm{ID} \beta$-blockers; $9=\mathrm{II}$ $\beta$-blockers; $10=$ DD calcium-channel antagonists; $11=$ ID calcium-channel antagonists; 12 = II calcium-channel antagonists; 13 = DD ACE inhibitors; 14 = ID ACE inhibitors; 15 = II ACE inhibitors.

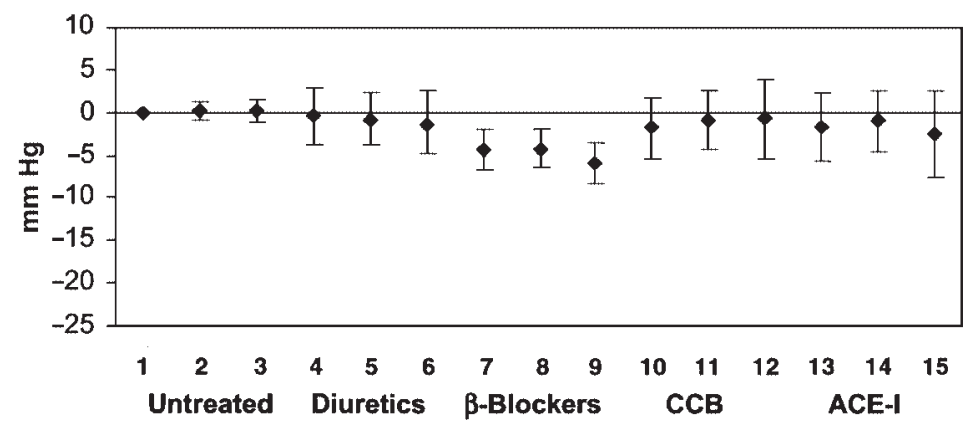

Figure 2. Adjusted mean diastolic blood pressure among subjects using antihypertensive drugs and subjects who were not treated for the 3 ACE genotypes; untreated subjects with the DD genotype were used as reference. ACE-I = angiotensin-converting enzyme inhibitors; $\mathrm{CCB}=$ calcium-channel antagonists. $1=\mathrm{DD}$ untreated; $2=\mathrm{ID}$ untreated; $3=\mathrm{II}$ untreated; 4 $=\mathrm{DD}$ diuretics; $5=\mathrm{ID}$ diuretics; $6=$ II diuretics; $7=\mathrm{DD} \beta$-blockers; $8=\mathrm{ID} \beta$-blockers; $9=$ II $\beta$-blockers; $10=$ DD calcium-channel antagonists; $11=$ ID calcium-channel antagonists; 12 = II calcium-channel antagonists; 13 = DD ACE inhibitors; 14 = ID ACE inhibitors; 15 = II ACE inhibitors. drug-gene interactions in smokers. However, none was found with any of the antihypertensive drug classes in current smokers (data not shown).

\section{Discussion}

Our findings in a white population suggest that the ACE I/D polymorphism does not influence the mean SBP or DBP difference in subjects using diuretics, $\beta$-blockers, calcium-channel antagonists, or ACE inhibitors, even after correcting for the DDD and other potential confounders.

Previous studies investigating the possible interaction between the I/D polymorphism and antihypertensives on blood pressure response have been inconclusive. ${ }^{3-12}$ Of the 8 studies that investigated the interaction between the ACE gene and ACE inhibitors on SBP and DBP in hypertensive patients, 3 suggested that the $\mathrm{D}$ allele had a stronger drug effect, ${ }^{8-10}$ while 2 indicated the I allele ${ }^{6,7}$ and 4 found no difference between the 2 alleles.-5, ${ }^{3-511}$ Regarding $\beta$-blockers, 2 studies found no drug- gene interaction effect on blood pressure ${ }^{4,12}$ and one found an interaction with thiazide diuretics. ${ }^{21}$ In that study, people on diuretics with one or 2 copies of the I allele of the ACE gene and one copy of the 460Trp allele of the $\alpha$-adducin gene showed the largest decrease in blood pressure.

The primary difference between those studies and ours is that ours was observational and previous studies were nonrandomized trials. In trials, treatment groups can be standardized with respect to dose, medication, duration of therapy, and time between blood pressure measurement and medication intake. In addition, it is possible that, in our study, the medication taken at the time of blood pressure measurement was not the initial drug chosen, but rather an alternative that, through a process of trial and error, was found to be the most effective. The potential overrepresentation of good responders increased the chance of finding a drug-gene interaction.

One strength of an observational study is that it resembles daily clinical practice, and analysis can be adjusted to account for potential confounders, such as dose and duration of therapy. Another strength of this study was the large sample size. However, a limitation is that no baseline measurement immediately preceding the commencement of an antihypertensive drug was available, and measurements were only taken every $2-3$ years, making it impossible to calculate the immediate effect after ad- 
ministration of an antihypertensive drug. Therefore, shortlived and temporary interactions were missed in this study.

Other limitations were the absence of a clinically confirmed diagnosis of hypertension and the overrepresentation of subjects with isolated systolic hypertension $(\sim 50 \%$ of untreated pts.). Given that the mean age of treated patients exceeded 70 years, it is reasonable to assume that there is also an overrepresentation of patients with isolated systolic hypertension in this group. Thus, the results cannot be generalized to all patients with hypertension.

Another potential limitation of our study is that we considered only one genetic polymorphism, which is linked to serum ACE activity but remains controversial in hypertension. Zhu et al. ${ }^{22}$ found 2 other ACE gene mutations that were linked with blood pressure and ACE serum concentrations. Therefore, it might be necessary to type additional markers.

Finally, observational studies may be vulnerable to selection, information, and confounding bias. Confounding is unlikely given that the data were adjusted for potential confounders, but it is impossible to adjust for unmeasured confounders. Race could have been an additional confounder; however, considering that less than $1 \%$ of the subjects had a different ethnic background, it is unlikely that this biased our results. More than $99 \%$ of our study population was white, so results can only be generalized to that race. Other variables exist that have an impact on blood pressure, such as exercise. Therefore, it is possible that we over- or underestimated the blood pressure-lowering effect of the antihypertensive drug classes. However, since this is likely the same for the various genotypes, this has not influenced the results of the drug-gene interaction.
Difference in blood pressure between treated and untreated patients could be the result of confounding by indication. Because a physician is free to choose either a particular antihypertensive drug or no treatment, specific patient characteristics may have influenced this decision. Therefore, we investigated the mean difference in blood pressure between users of the same antihypertensive drug therapy since they were most likely to have the same patient characteristics.

Information bias is also unlikely, as data on drug exposure were prospectively gathered via computerized pharmacies in a similar and unbiased fashion for all subjects. It is possible, however, that we under- or overestimated baseline characteristics for which we used self-reported data. In addition, we assumed that all prescribed pills were taken and thus may have overestimated adherence. Because this variable is likely the same for all 3 genotypes, it is unlikely to have biased our results. Selection bias is unlikely because this study was population based and loss to followup was negligible.

\section{Conclusions}

The caveats notwithstanding, our study suggests that the ACE I/D polymorphism of the ACE gene does not influence the mean blood pressure difference among users of low-ceiling diuretics, $\beta$-blockers, calcium-channel antagonists, or ACE inhibitors. Although it appears that the ACE I/D polymorphism does not have clinical relevance in the response to antihypertensive drugs, further investigations of short- and long-term outcomes are needed to reach definitive conclusions.

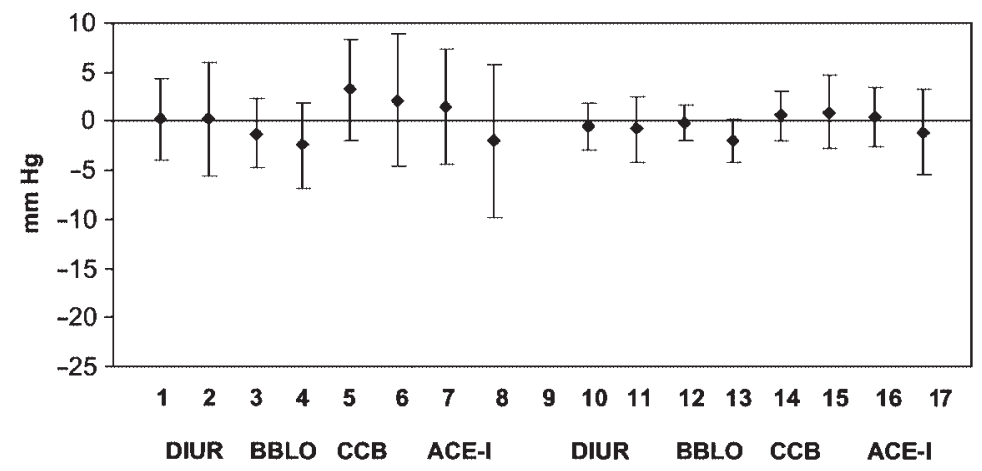

Figure 3. Adjusted mean systolic and diastolic blood pressure difference among subjects using antihypertensive drugs; the DD genotype of the antihypertensive drug class was used as reference. $A C E-I=$ angiotensin-converting enzyme inhibitors; $B B L O=\beta$-blockers; $C C B=$ calcium-channel antagonists; DBP = diastolic blood pressure; DIUR = diuretics; SBP = systolic blood pressure. 1 = ID vs DD genotype, diuretics, SBP; $2=\|$ vs DD genotype, diuretics, SBP; 3 = ID vs DD genotype, $\beta$-blockers, SBP; 4 = II vs DD genotype, $\beta$-blockers, SBP; $5=$ ID vs DD genotype, calcium-channel antagonists, SBP; $6=$ II vs DD genotype, calcium-channel antagonists, SBP; $7=$ ID vs DD genotype, ACE inhibitors, SBP; $8=1$ vs DD genotype, ACE inhibitors, SBP; $9=$ separation between SBP and DBP values; $10=$ ID vs DD genotype, diuretics, DBP; 11 = II vs DD genotype, diuretics, DBP; 12 = ID vs DD genotype, $\beta$-blockers, DBP; $13=$ II vs DD genotype, $\beta$-blockers, DBP; 14 = ID vs DD genotype, calcium-channel antagonists, DBP; 15 = II vs DD genotype, calcium-channel antagonists, DBP. $16=$ ID vs DD genotype, ACE inhibitors, DBP; 17 = II vs DD genotype, ACE inhibitors, DBP.
Hedi Schelleman MSc, PhD Candidate, Department of Epidemiology \& Biostatistics, Erasmus MC, Rotterdam, Netherlands; Department of Pharmacoepidemiology and Pharmacotherapy, Utrecht Institute for Pharmaceutical Sciences, Utrecht University, Utrecht, Netherlands

Olaf H Klungel PharmD PhD, Associate Professor, Department of Pharmacoepidemiology and Pharmacotherapy, Utrecht Institute for Pharmaceutical Sciences Cornelia M van Duijn PhD, Professor, Department of Epidemiology \& Biostatistics, Erasmus MC

Jacqueline CM Witteman PhD, Associate Professor, Department of Epidemiology \& Biostatistics, Erasmus MC

Albert Hofman MD PhD, Professor, Department of Epidemiology \& Biostatistics, Erasmus MC

Anthonius de Boer MD PhD, Professor, Department of Pharmacoepidemiology and Pharmacotherapy, Utrecht Institute for Pharmaceutical Sciences

Bruno HCh Stricker PhD, Professor, Department of Epidemiology \& Biostatistics, Erasmus MC

Reprints: Dr. Stricker, Department of Epidemiology \& Biostatistics, Erasmus MC, PO Box 1738, 3000 DR Rotterdam, Netherlands, fax 0031104089382 , b.stricker@erasmusmc.nl

The Netherlands Heart Foundation financially supported this study through grant number 2001.064. The 
Rotterdam study was funded by the Netherlands Organization for Scientific Research and the Municipality of Rotterdam.

\section{References}

1. Rigat B, Hubert C, Alhenc-Gelas F, Cambien F, Corvol P, Soubrier F. An insertion/deletion polymorphism in the angiotensin I-converting enzyme gene accounting for half the variance of serum enzyme levels. J Clin Invest 1990;86:1343-6.

2. Schunkert H. Polymorphism of the angiotensin-converting enzyme gene and cardiovascular disease. J Mol Med 1997;75:867-75.

3. Hingorani AD, Jia H, Stevens PA, Hopper R, Dickerson JE, Brown MJ. Renin-angiotensin system gene polymorphisms influence blood pressure and the response to angiotensin converting enzyme inhibition. J Hypertens 1995; 13:1602-9.

4. Dudley C, Keavney B, Casadei B, Conway J, Bird R, Ratcliffe P. Prediction of patient responses to antihypertensive drugs using genetic polymorphisms: investigation of renin-angiotensin system genes. J Hypertens 1996;14:259-62.

5. Nakano Y, Oshima T, Watanabe M, Matsuura H, Kajiyama G, Kambe M. Angiotensin I-converting enzyme gene polymorphism and acute response to captopril in essential hypertension. Am J Hypertens 1997;10: 1064-8.

6. Ohmichi N, Iwai N, Uchida Y, Shichiri G, Nakamura Y, Kinoshita M. Relationship between the response to the angiotensin converting enzyme inhibitor imidapril and the angiotensin converting enzyme genotype. Am J Hypertens 1997;10:951-5.

7. O'Toole L, Stewart M, Padfield P, Channer K. Effect of the insertion/ deletion polymorphism of the angiotensin-converting enzyme gene on response to angiotensin-converting enzyme inhibitors in patients with heart failure. J Cardiovasc Pharmacol 1998;32:988-94.

8. Mondorf UF, Russ A, Wiesemann A, Herrero M, Oremek G, Lenz T. Contribution of angiotensin I converting enzyme gene polymorphism and angiotensinogen gene polymorphism to blood pressure regulation in essential hypertension. Am J Hypertens 1998;11:174-83.

9. Stavroulakis GA, Makris TK, Hatzizacharias AN, Anastasiadis G, Triposkoadis $\mathrm{P}$, Kyriakidis MK. Predicting response to chronic antihypertensive treatment with fisinopril: the role of the angiotensin-converting enzyme gene polymorphism. Cardiovasc Drugs Ther 2000;14:427-32.

10. Li X, Du Y, Huang X. Correlation of angiotensin-converting enzyme gene polymorphism with effect of antihypertensive therapy by angiotensin-converting enzyme inhibitor. J Cardiovasc Pharmacol Ther 2003;8:25-30.

11. Arnett DK, Davis BR, Ford CE, et al. Pharmacogenetic association of the angiotensin-converting enzyme insertion/deletion polymorphism on blood pressure and cardiovascular risk in relation to antihypertensive treatment. The Genetics of Hypertension-Associated Treatment (GenHAT) Study. Circulation 2005;111:3374-83.

12. Kurland L, Melhus H, Karlsson J, et al. Angiotensin converting enzyme gene polymorphism predicts blood pressure response to angiotensin II receptor type 1 antagonist treatment in hypertensive patients. J Hypertens 2001;19:1783-7.

13. Blumenfeld JD, Sealey JE, Mann SJ, et al. Beta-adrenergic receptor blockade as a therapeutic approach for suppressing the renin-angiotensin-aldosterone system in normotensive and hypertensive subjects. Am J Hypertens 1999;12:451-9.

14. Weisser B, Ripka O. Long-term diuretic therapy: effects of dose reduction on antihypertensive efficacy and counterregulatory systems. J Cardiovasc Pharmacol 1992;19:361-6.

15. Muller FB, Bolli P, Erne P, Kiowski W, Buhler FR. Use of calcium antagonists as monotherapy in the management of hypertension. Am J Med 1984;77:11-5.

16. Hofman A, Grobbee DE, de Jong PT, van den Ouweland FA. Determinants of disease and disability in the elderly: the Rotterdam Elderly Study. Eur J Epidemiol 1991;7:403-22.

17. Lindpaintner K, Pfeffer MA, Kreutz R, et al. A prospective evaluation of an angiotensin-converting-enzyme gene polymorphism and the risk of ischemic heart disease. N Engl J Med 1995;332:706-11.

18. Guidelines for ATC classification and DDD assignment. 3rd ed. Oslo, Norway: WHO Collaborating Centre for Drug Statistics Methodology, 2000.

19. Yu XL, Jin XR, Wang DX. Effects of cigarette smoking on the function of metabolizing arachidonic acid and angiotensin I in the isolated perfused rat lungs. J Tongji Med Univ 1992;12:201-4.
20. Schut AF, Sayed-Tabatabaei FA, Witteman JC, et al. Smoking-dependent effects of the angiotensin-converting enzyme gene insertion/deletion polymorphism on blood pressure. J Hypertens 2004;22:313-9.

21. Sciarrone MT, Stella P, Barlassina C, et al. ACE and alpha-adducin polymorphism as markers of individual response to diuretic therapy. Hypertension 2003;41:398-403.

22. Zhu X, Bouzekri N, Southam L, et al. Linkage and association analysis of angiotensin I-converting enzyme (ACE)-gene polymorphisms with ACE concentration and blood pressure. Am J Hum Genet 2001;68:113948.

\section{EXTRACTO}

ANTECEDENTES: A pesar de la disponibilidad de una gran variedad de medicamentos antihipertensivos efectivos, el control inadecuado de la presión sanguínea continúa siendo un problema. Hay evidencia de que el gen de la enzima convertidora de la angiotensina (ECA) modifica la respuesta a los medicamentos antihipertensivos, aunque los resultados no son concluyentes.

OBJETIVO: Investigar si el polimorfismo de inserción/remoción del gen de la ECA modifica la diferencia media en presión sanguínea sistólica y diastólica entre los consumidores de diuréticos, bloquedores beta, antagonistas de los canales de calcio, y/o los inhibidores de la ECA.

MÉTODOS: Se usaron los datos del estudio de Rotterdam, un estudio de cohorte prospectivo de población llevado a cabo en los Países Bajos e iniciado en el año 1990. Se incluyeron 7983 individuos mayores de o de 55 años de edad. El criterio para ser incluído en la evaluación incluyó una elevación de la presión sanguínea en uno o más exámenes y/o estar recibiendo monoterapia con un diurético, bloqueador beta, antagonista de los canales de calcio, o un inhibidor de la ECA. Se usó un modelo lineal generalizado marginal para evaluar la asociación entre la diferencia media de presión sanguínea sistólica/diastólica y las clases de medicamentos antihipertensivos estraficando de acuerdo a los 3 genotipos.

RESULTADOS: Se incluyeron 3025 individuos hipertensivos con un total de 6500 medidas de presión sanguínea. De estos, el 28.3\%, 51.4\%, y $20.3 \%$ poseían los genotipos DD, ID, y II, respectivamente. La diferencia media en la presión sanguínea entre los genotipos II y DD fue de $0.23 \mathrm{~mm} \mathrm{Hg}$ (95\% IC -5.48 a 5.94) para los diuréticos, $-2.41 \mathrm{~mm} \mathrm{Hg}$ (95\% IC -6.72 a 1.90) para los bloqueadores beta, $2.12 \mathrm{~mm} \mathrm{Hg}(95 \%$ IC - 4.64-8.89) para los antagonistas de los canales de calcio, y -2.01 $\mathrm{mm} \mathrm{Hg}$ (95\% IC -9.82 a 5.79) para los consumidores de inhibidores de la ECA.

CONCLUSIONES: La diferencia media ajustada de presión sistólica y diastólica entre los consumidores de diuréticos, bloqueadores beta, antagonistas de los canales de calcio, o inhibidores de la ECA no fue modificada por el polimorfismo de inserción/remoción de la ECA.

Encarnación C Suárez

\section{RÉSUMÉ}

INTRODUCTION: Malgré l'existence de nombreux médicaments efficaces, le contrôle de l'hypertension demeure sous-optimal. Des indices suggèrent que le gène de l'enzyme de conversion de l'angiotensine (ECA) modifie la réponse aux médicaments anti-hypertenseurs bien que les résultats actuels soient non concluants.

OBJECTIF: Évaluer si l'insertion/délition du polymorphisme du gène de l'ECA modifie la réponse de la tension artérielle chez des sujets traités avec les diurétiques, les $\beta$-bloquants, les bloquants calciques, ou les inhibiteurs de l'ECA.

MÉTHODES: Les données utilisées étaient celles de l'étude de Rotterdam, une étude prospective de population réalisée aux Pays-Bas en 1990 regroupant 7983 sujets de 55 ans et plus. Les données de 3 études transversales subséquentes ont été utilisées. Les sujets ont été inclus s'ils présentaient une tension artérielle élevée lors d'au moins une évaluation et/ou recevaient une monothérapie composée de diurétiques, de $\beta$ bloquants, de bloquants calciques, ou d'inhibiteurs de l'ECA. Un 


\section{H Schelleman et al.}

modèle général linéaire marginal a été utilisé pour analyser l'association entre la différence moyenne des tensions systoliques/diastoliques et les classes d'antihypertenseurs en stratifiant pour 3 génotypes.

RÉSULTATS: Au total, 3025 patients hypertendus ont été inclus totalisant 6500 mesures de la tension artérielle. Les génotypes étaient DD, ID, et II dans $28.3 \%$, $51.4 \%$, et $20.3 \%$ des cas, respectivement. La différence moyenne des tensions systoliques entre les groupes II et DD était de $0.23 \mathrm{~mm} \mathrm{Hg}$ (IC 95\% -5.48 à 5.94) pour les diurétiques, $-2.41 \mathrm{~mm} \mathrm{Hg}$ (IC $95 \%-6.72$ à 1.90) pour les $\beta$-bloquants, $2.12 \mathrm{~mm} \mathrm{Hg}$ (IC 95\%
-4.64 à 8.89 ) pour les bloquants calciques, et -2.01 (IC 95\%-9.82 à 5.79) pour les inhibiteurs de l'ECA.

CONCLUSIONS: La différence moyenne ajustée entre les presions systoliques et diastoliques entre les diurétiques, les $\beta$-bloquants, les bloquants calciques, et les inhibiteurs de l'ECA n'a pas été affectée par l'insertion/délition du polymorphisme de l'ECA.

Marc Parent 